JARES, Vol. 4 No. 1 March, 2019; p-ISSN: 2502-826X; e-ISSN: 2503-1163

Copyrights@ Balitar Islamic University, Blitar, Indonesia;

https://ejournal.unisbablitar.ac.id/index.php/jares

Citation: Alam, S., \& Alam, R. (2019). THE EFFECT OF PERSONAL ETHICAL PHILOSOPHY, INTERNAL LOCUS OF CONTROL AND ACADEMIC CULTURE ON PROFESSIONAL COMPETENCE OF ACCOUNTANT EDUCATORS IN PRIVATE UNIVERSITIES IN MAKASSAR. JARES (Journal of Academic Research and Sciences), 4(1), 13-27. https://doi.org/10.30957/jares.v4i1.692

\title{
THE EFFECT OF PERSONAL ETHICAL PHILOSOPHY, INTERNAL LOCUS OF CONTROL AND ACADEMIC CULTURE ON PROFESSIONAL COMPETENCE OF ACCOUNTANT EDUCATORS IN PRIVATE UNIVERSITIES IN MAKASSAR
}

\author{
Syamsu Alam \\ Lecturers of Accounting Major, Indonesia Muslim University, Makassar \\ Email: ancu_alam@yahoo.com \\ Roslina Alam \\ Lecturers of Accounting Major, Indonesia Muslim University, Makassar \\ Email: roslinamawar@gmail.com
}

\begin{abstract}
This research aims at (1) exploring individual aspects of accountant educators in shaping professional accountants, and (2) situational aspects utilized by accountant educators as the media in shaping professional accountants in Makassar The independent variable of this research included Personal Ethical Philosophy, Internal Locus of Control, and Academic Culture, while the dependent variable was the Professional Competence of Accountant Educators (Y). The units of analysis, as well as the respondents, were 132 accountant educators in Makassar. To determine the sample, Simple Proportional Sampling with minimal respondent by Taro Yamane was utilized. Data analysis deployed multiple linear regression with error tolerance $(\alpha)$ of $5 \%$. The result shows that Personal Ethical Philosophy significantly affected professional competence, with the t-calculated of 2.085. Internal Locus of Control also significantly affected professional competence, with the t-calculated of 2.158. Academic culture, with the t-calculated of 2.146, also significantly affected the professional competence of accountant educators.
\end{abstract}

\section{Keywords: Personal Ethical Philosophy, Internal Locus of Control, Academic Culture, Professional Competence}

\section{INTRODUCTION}

Higher education is an educational environment having the community or society called the academic community. It has academic activities and rules. Higher education is an academic institution having a particular atmosphere, that is, academic atmosphere. The characteristics of academic society are critical, objective, analytical, creative and constructive, willing to accept criticism, respecting the time and scientific achievement, prejudice-free, communicative partnership, possessing and valuing academic norms and decency as well as scientific tradition, dynamic, and oriented to the future.

The success of the higher education management as an educational institution shaping intelligent and independent generations are mainly determined by Human Resources of the institution. In the same way, the 
JARES, Vol. 4 No. 1 March, 2019; p-ISSN: 2502-826X; e-ISSN: 2503-1163

Copyrights@ Balitar Islamic University, Blitar, Indonesia;

https://ejournal.unisbablitar.ac.id/index.php/jares

Citation: Alam, S., \& Alam, R. (2019). THE EFFECT OF PERSONAL ETHICAL PHILOSOPHY, INTERNAL LOCUS OF CONTROL AND ACADEMIC CULTURE ON PROFESSIONAL COMPETENCE OF ACCOUNTANT EDUCATORS IN PRIVATE UNIVERSITIES IN MAKASSAR. JARES (Journal of Academic Research and Sciences), 4(1), 13-27. https://doi.org/10.30957/jares.v4i1.692

performance of the Accounting Department-a learning unit in a higher education that will shape professional accountants- is determined by the knowledgeable and skilled accountant educators as the change agents. A good performance of accountant educators will support the attainment of the institution's goals. The improvement of Accountant Educators will bring about the advancement of the Accounting Department to shape professional accountants. Performance is a comparison between the achieved work's results and the acceptable standard. The performance of Accountant Educators is determined/measured from the professional competence they have in doing their duties and responsibilities in the field of accounting. This ability is represented by their competence as an educator. Therefore, efforts to improve the performance of accountant educators are the most critical challenge for the higher education's management since to achieve the goals and viability of Accounting Department, it depends on the competences of human resources-Accountant Educators- notably professional competence.

The success of an institution in achieving its goals is measured by how good the competences of human resources can be built. An institution managing the Accounting Department which will shape professional accountants should consider professional competence aspect. Accountant Educators will understand and be aware of their duties, how to do, when to start and finish, the expected results, and to whom they must be responsible for the job done.

Professional competence is an ability to master the learning materials widely and deeply that enables educators to supervise students in meeting standard competencies set by the National Standard of Education. Professional competence is the ability to master science, technology, art, and culture being taught.

The professional competence of accountant educators relates to the profession demanding any skills in the field of education and profession. Professional competence is a fundamental ability of accountant educators in understanding the learning and behaviors of humans, materials, acceptable attitudes about learning environment, and techniques in transferring knowledge.

Aspects that stimulate the improvement of performance are affected by the internal aspect and external aspect of an individual. Individual aspects included personal ethical philosophy, locus of control, and academic culture. Ethical awareness and professionalism play a critical role for a professional (Louwers, et al., 1997 in Husein, 2004). This is because in doing his profession, an accountant must consistently 
JARES, Vol. 4 No. 1 March, 2019; p-ISSN: 2502-826X; e-ISSN: 2503-1163

Copyrights@ Balitar Islamic University, Blitar, Indonesia;

https://ejournal.unisbablitar.ac.id/index.php/jares

Citation: Alam, S., \& Alam, R. (2019). THE EFFECT OF PERSONAL ETHICAL PHILOSOPHY, INTERNAL LOCUS OF CONTROL AND ACADEMIC CULTURE ON PROFESSIONAL COMPETENCE OF ACCOUNTANT EDUCATORS IN PRIVATE UNIVERSITIES IN MAKASSAR. JARES (Journal of Academic Research and Sciences), 4(1), 13-27. https://doi.org/10.30957/jares.v4i1.692

encounter ethical dilemmas involving choices among the contradicted values. In facing an ethical dilemma situation, ethical perception and consideration of a professional auditor play an important role in making ethical decisions.

Some studies about ethical codes of accountants have been conducted by some researchers. Desriani (1993) showed that there were different significant perceptions among the group of public accountants. Sihwahjoeni and Gudono (2000) empirically tested the perception on Ethical Codes of Indonesian Accountant among seven accountant groups covering public accountants, accountant educators as public accountants, accountant educators as a management accountant, and accountant educators as government accountants, showing that there was no any different perception about the importance of ethical codes of accountants.

Several studies also have been carried out focusing on personal ethical philosophy. Khomsiyah and Indriantoro (1998) disregarded the effect of personal ethical philosophy on ethical consideration. The effect of personal ethical philosophy on ethical consideration is interesting to study since a person's ethical consideration will determine his decision-making when encountering ethical dilemmas.

The improvement of a person's performance is also affected by an individual factor namely locus of control. Sarita and Agustia (2009) stated that locus of control shows how far someone believes that he can control factors affecting himself. Someone who has an internal locus of control tends to use pressure or make bigger efforts compared to those who have an external locus of control believing in the visible efforts or rewards. Ayudiati (2010) mentioned that locus of control positively and significantly affected the employees' performance.

In addition to individual factors, personal performance is influenced by external aspects or situational aspects such as organizational culture. Academic culture as a totality of life and academic activities is understood, comprehended, and applied by academic society. Academic culture is determined by university culture, not only aiming at improving intellectual ability, but also honesty, truth, and service to humanity.

Academic culture is a universality that must be possessed by every person involving themselves in academic activity. This culture should be attributed to every academician in higher education, either lecturers or students. This is due to the importance of academic culture which refers to the way how the complex and multicultural academic society exists in an institution founding itself on the scientific truthfulness and objectivity. 
Citation: Alam, S., \& Alam, R. (2019). THE EFFECT OF PERSONAL ETHICAL PHILOSOPHY, INTERNAL LOCUS OF CONTROL AND ACADEMIC CULTURE ON PROFESSIONAL COMPETENCE OF ACCOUNTANT EDUCATORS IN PRIVATE UNIVERSITIES IN MAKASSAR. JARES (Journal of Academic Research and Sciences), 4(1), 13-27. https://doi.org/10.30957/jares.v4i1.692

Professional Competence of Accountant Educators is highly needed in achieving the goals of an organization. Such competence closely relates to some factors namely personal ethical philosophy, internal locus of control, and academic culture. Based on the elaboration above, the researchers are interested to conduct research entitled the effect of Personal Ethical Philosophy, Internal Locus of Control, and Academic Culture on Professional Competence of Accountant Educators in Makassar.

In line with the background of the study, the research problems are formulated as follows.

1. Does Personal Ethical Philosophy affect professional competence of accountant educators in Makassar?

2. Does Internal Locus of Control affect professional competence of accountant educators in Makassar?

3. Does Academic Culture affect professional competence of accountant educators in Makassar?

\section{RESEARCH METHOD}

\section{A. Research Object}

Variable is an object or point of interest in research, while the place where the variable is attributed to is called subject. Objects of this research were Personal Ethical Philosophy, Internal Locus of Control, Academic Culture, and Professional Competence of Accountant Educators.

\section{B. Operational of Variable}

In order that this research can be done like what the researchers expected, several research elements as the basis of scientific research stated in the operational of research variable need to be understood. This research consisted of two variables namely independent variable $(X)$, and dependent variable $(Y)$

- Independent variables in this research were:

- Personal Ethical Philosophy, $\left(X_{1}\right)$.

- Internal Locus of Control $\left(\mathrm{X}_{2}\right)$.

- Academic Culture $\left(\mathrm{X}_{3}\right)$.

- The dependent variable in this research was the Professional Competence of Accountant Educators.

\section{Population and Technique of Determining Sample Research Population}

According to Sekaran (2003) population is the entire group of people, events, or things of interest that the researcher wishes to investigate. 
JARES, Vol. 4 No. 1 March, 2019; p-ISSN: 2502-826X; e-ISSN: 2503-1163

Copyrights@ Balitar Islamic University, Blitar, Indonesia;

https://ejournal.unisbablitar.ac.id/index.php/jares

Citation: Alam, S., \& Alam, R. (2019). THE EFFECT OF PERSONAL ETHICAL PHILOSOPHY, INTERNAL LOCUS OF CONTROL AND ACADEMIC CULTURE ON PROFESSIONAL COMPETENCE OF ACCOUNTANT EDUCATORS IN PRIVATE UNIVERSITIES IN MAKASSAR. JARES (Journal of Academic Research and Sciences), 4(1), 13-27. https://doi.org/10.30957/jares.v4i1.692

Populations in this research were Accountant Educators (Accounting Lecturers) in Makassar.

\section{Sample}

Accountant Educators as the sample in this research were the permanent lecturers involved in the learning activity at the Accounting Department. The technique of selecting respondents was Simple Proportional Sampling using the formula:

$$
\text { Proporsi }=\frac{\sum \text { Dosen di PT N }}{\text { Total Dosen PT di Kopertis IX }} \text { X Responden yang diinginkan }
$$

Selection of minimal respondents (the expected respondents) utilized the formula from Taro Yamane as cited in Rakhmad (1998: 82) as follows:

Explanation:

$$
\mathrm{n}=\frac{N}{N \cdot d^{2}+1}
$$

$\mathrm{n}=$ sample size

$\mathrm{N}=$ population size

$d^{2}=$ the stated precision of $5 \%(0,05)$

$1=$ intercept number

Therefore:

$$
\begin{aligned}
& \mathrm{n}=\frac{196}{196 \cdot(0,05)^{2}+1} \\
& \mathrm{n}=\frac{196}{196 \cdot(0,0025)+1} \\
& \mathrm{n}=\frac{196}{0,49+1} \\
& \mathrm{n}=\frac{196}{1,49}=131.54=132 \text { Accountant Educators (as the minimal } \\
& \text { respondents) }
\end{aligned}
$$

The size of $\mathrm{n}$ is then allocated using the method of proportional allocation (Moh. Nasir 2005: 306) as follows:

Where: $\quad n_{i}=$ sample size at stratum $\mathrm{i}$

$$
\mathrm{n}_{\mathrm{i}}=\frac{\mathrm{N}_{\mathrm{i}}}{\mathrm{N}} \times \mathrm{n}
$$

$\mathrm{N}_{\mathrm{i}}=$ population size at stratum $\mathrm{i}$

$\mathrm{N}=$ the entire size of the population

$\mathrm{n}$ = sample size of population 
JARES, Vol. 4 No. 1 March, 2019; p-ISSN: 2502-826X; e-ISSN: 2503-1163

Copyrights@ Balitar Islamic University, Blitar, Indonesia;

https://ejournal.unisbablitar.ac.id/index.php/jares

Citation: Alam, S., \& Alam, R. (2019). THE EFFECT OF PERSONAL ETHICAL PHILOSOPHY, INTERNAL LOCUS OF CONTROL AND ACADEMIC CULTURE ON PROFESSIONAL COMPETENCE OF ACCOUNTANT EDUCATORS IN PRIVATE UNIVERSITIES IN MAKASSAR. JARES (Journal of Academic Research and Sciences), 4(1), 13-27. https://doi.org/10.30957/jares.v4i1.692

The proportion of respondents was as follows:

Proporsi $=\frac{8}{196} \times 132=5,39$ atau 5 Akuntan Pendidik
Proporsi $=\frac{6}{196} \times 132=4,04$ atau 4 Akuntan Pendidik
Proporsi $=\frac{13}{196} \times 132=8,75$ atau 9 dosen And so forth

Table 3.1 depicts the number of selected respondents:

Table 3.1

Accountant Educators in Makassar as the Respondents

\begin{tabular}{|c|l|c|c|}
\hline \multirow{2}{*}{ No INSTITUTION } & \multicolumn{1}{|c|}{ Selected Respondent } \\
\cline { 3 - 4 } & & $\sum$ Lecturers & $\sum$ Lecturers \\
\hline 1 & STIE Amkop Makassar & 8 & 5.39 \\
\hline 2 & STIE Bajiminasa Makassar & 6 & 4.04 \\
\hline 3 & STIE Bongaya YPBUP Makassar & 13 & 8.76 \\
\hline 4 & STIE Indonesia Makassar & 9 & 6.06 \\
\hline 5 & STIE LPI Makassar & 7 & 4.71 \\
\hline 6 & STIE Nobel Indonesia Maksr & 10 & 6.73 \\
\hline 7 & STIE Nusantara Makassar & 7 & 4.71 \\
\hline 8 & STIE Rezky Makassar & 4 & 2.69 \\
\hline 9 & STIE Tri Dharma Nusantara & 6 & 4.04 \\
& Makassar & & \\
\hline 10 & STIE Wira Bhakti Makassar & 5 & 3.37 \\
\hline 11 & STIE YPUP Makassar & 11 & 7.41 \\
\hline 12 & STIE Makassar Maju Makassar & 5 & 3.37 \\
\hline 13 & STIE Partia Arta Makassar & 6 & 4.04 \\
\hline 14 & STIM Nitro Makassar & 10 & 6.73 \\
\hline 15 & STIM LPI Makassar & 6 & 4.04 \\
\hline 16 & Univ 45 Makassar & 4 & 2.69 \\
\hline 17 & Univ Atma Jaya Makassar & 17 & 11.45 \\
\hline 18 & Univ Cokroaminoto Makassar & 6 & 4.04 \\
\hline 19 & Univ Indonesia Timur Makassar & 8 & 5.39 \\
\hline 20 & Univ Kristen Indonesia Paulus & 13 & 8.76 \\
\hline 21 & Unakassar & 7 & 4.71 \\
\hline 22 & Univ Muslim Indonesia Makassar & 16 & 10.78 \\
\hline 23 & Univ Veteran RI Makassar & 7.71 \\
\hline & Total & 73 \\
\hline
\end{tabular}

Analyzed data

Source: Coordinator of Private Universities (Kopertis) Region IX Sulawesi, 
Citation: Alam, S., \& Alam, R. (2019). THE EFFECT OF PERSONAL ETHICAL PHILOSOPHY, INTERNAL LOCUS OF CONTROL AND ACADEMIC CULTURE ON PROFESSIONAL COMPETENCE OF ACCOUNTANT EDUCATORS IN PRIVATE UNIVERSITIES IN MAKASSAR. JARES (Journal of Academic Research and Sciences), 4(1), 13-27. https://doi.org/10.30957/jares.v4i1.692

\section{A. The technique of Data Test Test of Validity}

Validity test was conducted to investigate whether the instruments really measured what should be measured. Instruments with high validity will have low error tolerance; they provided the results according to their intent. Validity test in this research utilized Product Moment correlation.

\section{Test of Reliability}

The reliability test was done to know whether the instruments show the precision, accuracy, stability, and consistency in revealing specific phenomena from a group of individuals at different times. In this research, the reliability test employed a split half technique from Spearman-Brown

\section{B. Method of Data Analysis}

Data analysis is the ways of analyzing the collected data, followed by providing interpretation. The result of data analysis was to answer the formulated problems. Data analysis was carried out by utilizing multiple linear regression with the following equation:

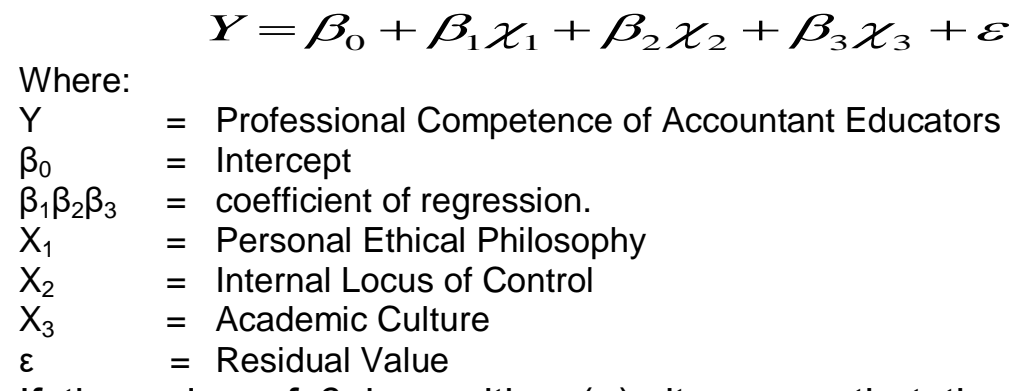

If the value of $\beta$ is positive $(+)$, it means that there is a positive correlation between the independent variable and dependent variable. In other words, the increase/decrease of the independent variable comes with the increase/decrease of the dependent variable.

Meanwhile, if the value of $\beta$ is negative (-), it shows that there is a negative correlation between the independent variable and dependent variable. Each of the increase of the independent variable will be followed by the decrease of the independent variable and vice versa. Error tolerance (a) was approved $5 \%$.

\section{RESULT AND DISCUSSION}

\section{A. Analysis Result Multiple Linear Regression}

The result of multiple linear regression in measuring the effect of 
JARES, Vol. 4 No. 1 March, 2019; p-ISSN: 2502-826X; e-ISSN: 2503-1163

Copyrights@ Balitar Islamic University, Blitar, Indonesia;

https://ejournal.unisbablitar.ac.id/index.php/jares

Citation: Alam, S., \& Alam, R. (2019). THE EFFECT OF PERSONAL ETHICAL PHILOSOPHY, INTERNAL LOCUS OF CONTROL AND ACADEMIC CULTURE ON PROFESSIONAL COMPETENCE OF ACCOUNTANT EDUCATORS IN PRIVATE UNIVERSITIES IN MAKASSAR. JARES (Journal of Academic Research and Sciences), 4(1), 13-27. https://doi.org/10.30957/jares.v4i1.692

Personal Ethical Philosophy, Internal Locus of Control, and Academic Culture of Accountant Educators in the form of SPSS output is depicted in the following table:

Table 4.1

Regression Result for Personal Ethical Philosophy, Internal Locus of Control, and Academic Culture on Professional Competence of Accountant Educators

Coefficients

\begin{tabular}{|c|c|c|c|c|c|c|c|}
\hline \multirow[b]{2}{*}{ del } & \multicolumn{2}{|c|}{$\begin{array}{l}\text { nstandardized } \\
\text { Coefficients }\end{array}$} & \multirow{2}{*}{$\begin{array}{l}\text { andardized } \\
\text { oefficients } \\
\text { Beta }\end{array}$} & \multirow[b]{2}{*}{$\mathrm{T}$} & \multirow[b]{2}{*}{ Sig. } & \multicolumn{2}{|c|}{ linearity Statistics } \\
\hline & B & d. Error & & & & lerance & VIF \\
\hline Jnstant) & 3,952 & 4,441 & & 2,016 & .049 & & \\
\hline $\begin{array}{l}\text { Personal Ethical Philosophy } \\
\text { (X1) }\end{array}$ & .210 & .101 & 247 & 2,085 & .042 & .665 & 1.504 \\
\hline $\begin{array}{l}\text { Internal Locus of Control } \\
\text { (X2) }\end{array}$ & .210 & .097 & .293 & 2,158 & .035 & .505 & 1,980 \\
\hline Academic Culture (X3) & .274 & 128 & .274 & 2,146 & .036 & .574 & 1,743 \\
\hline
\end{tabular}

a. Dependent Variable : Professional Competence of Accountant Educators $(\mathrm{Y})$ Source: Analyzed data, 2015

Based on Table 4.1, the model of the regression equation for the effect of Personal Ethical Philosophy, Internal Locus of Control, and Academic Culture on Professional Competence of Accountant Educators of Accounting Department is as follows:

$$
Y=8,952+0,210 X_{1}+0,210 X_{2}+0,274 X_{3}+e
$$

Referring to the equation above, it can be said as follows:

1. The intercept value was 8.952, indicating that without the effect of Personal Ethical Philosophy, Internal Locus of Control, and Academic Culture, Professional Competence of Accountant Educators was 8.95\%.

2. The coefficient value of Personal Ethical Philosophy regression was 0.210 , meaning that in every single improvement of leadership, Professional Competence of Accountant Educators increased by $21 \%$.

3. The coefficient value of Internal Locus of Control regression was 0.210, revealing that in every single improvement of Internal Locus of Control, Professional Competence of Accountant Educators increased by $21 \%$.

4. The coefficient value of Academic Culture regression was 0.274 , signaling that in every single improvement of Academic Culture, Professional Competence of Accountant Educators increased by $27.4 \%$. 
JARES, Vol. 4 No. 1 March, 2019; p-ISSN: 2502-826X; e-ISSN: 2503-1163

Copyrights@ Balitar Islamic University, Blitar, Indonesia;

https://ejournal.unisbablitar.ac.id/index.php/jares

Citation: Alam, S., \& Alam, R. (2019). THE EFFECT OF PERSONAL ETHICAL PHILOSOPHY, INTERNAL LOCUS OF CONTROL AND ACADEMIC CULTURE ON PROFESSIONAL COMPETENCE OF ACCOUNTANT EDUCATORS IN PRIVATE UNIVERSITIES IN MAKASSAR. JARES (Journal of Academic Research and Sciences), 4(1), 13-27. https://doi.org/10.30957/jares.v4i1.692

\section{t-Test}

To figure out whether there was a significant effect of Personal Ethical Philosophy, Internal Locus of Control, and Academic Culture on Professional Competence of Accountant Educators, a t-test was performed. The result of t-statistics using SPSS program revealed the following findings:

Table 4.2

The result of t-Test for Personal Ethical Philosophy, Internal Locus of Control, and Academic Culture on Professional Competence of Accountant Educators

\begin{tabular}{|c|c|c|c|c|c|}
\hline \multirow[b]{2}{*}{ del } & \multicolumn{2}{|c|}{$\begin{array}{l}\text { Unstandardized } \\
\text { Coefficients }\end{array}$} & \multirow{2}{*}{$\begin{array}{l}\text { andardized } \\
\text { oefficients } \\
\text { Beta }\end{array}$} & \multirow[b]{2}{*}{$\mathrm{t}$} & \multirow[b]{2}{*}{ Sig. } \\
\hline & $\mathrm{B}$ & itd. Error & & & \\
\hline Jnstant) & 8,952 & 4,441 & & 2,016 & .049 \\
\hline $\begin{array}{l}\text { Personal Ethical Philosophy } \\
\text { (X1) }\end{array}$ & .210 & .101 & 247 & 2,085 & .042 \\
\hline Internal Locus of Control (X2) & .210 & .097 & .293 & 2,158 & .035 \\
\hline Academic Culture (X3) & 274 & 128 & 274 & 2,146 & .036 \\
\hline
\end{tabular}

Source: Analyzed data, 2015

The result of t-test was as follows:

1. The t-calculated of Personal Ethical Philosophy on Professional Competence of Accountant Educators, 2.085. It was more than the ttable, 2.002, with the significance value of 0.042 . This significance value was less than the significance level $(\alpha)$ of 0.05 . This result indicated that Personal Ethical Consideration significantly affected Professional Competence of Accountant Educators; therefore, the hypothesis testing for Ha was accepted.

2. The t-calculated of Personal Ethical Philosophy on Professional Competence of Accountant Educators was 2.185. It was more than the t-table, 2.002, with the significance value of 0.035 . This significance value was less than the significance level $(\alpha)$ of 0.05 . This result revealed that Internal Locus of Control significantly affected Professional Competence of Accountant Educators; therefore, the hypothesis testing for Ha was accepted.

3. The result of t-test for Academic Culture on Professional Competence of Accountant Educators resulted in the t-calculated of 2.146. This value was more than the t-table of 2.002 , with the significance value of 0.036 . This significance value $(\alpha)$ was less than 0.05 . This result showed that Academic Culture significantly affected Professional Competence of Accountant Educators; therefore, the hypothesis testing for $\mathrm{Ha}$ was accepted. 
JARES, Vol. 4 No. 1 March, 2019; p-ISSN: 2502-826X; e-ISSN: 2503-1163

Copyrights@ Balitar Islamic University, Blitar, Indonesia;

https://ejournal.unisbablitar.ac.id/index.php/jares

Citation: Alam, S., \& Alam, R. (2019). THE EFFECT OF PERSONAL ETHICAL PHILOSOPHY, INTERNAL LOCUS OF CONTROL AND ACADEMIC CULTURE ON PROFESSIONAL COMPETENCE OF ACCOUNTANT EDUCATORS IN PRIVATE UNIVERSITIES IN MAKASSAR. JARES (Journal of Academic Research and Sciences), 4(1), 13-27. https://doi.org/10.30957/jares.v4i1.692

Referring to the results of the t-test, Internal Locus of Control had the most significant effect on Professional Competence of Accountant Educators; the t-calculated was 2.158, more than the t-calculated of Academic Culture, 2.146, and Personal Ethical Philosophy, 2.085. Amid the three independent variables, the management of the Accounting Department should provide the better Internal Locus of Control. After providing a beneficial Internal Locus of Control, it is then crucial to create Academic Culture based on the rules, and shape a leader who understands his personnel, and cooperates with them.

\section{F Test}

To investigate the significant effect of Personal Ethical Philosophy, Internal Locus of Control, and Academic Culture altogether on Professional Competence of Accountant Educators, F test was performed. Table 4.3 shows the result of F-statistics testing:

\section{Table 4.3}

The Result of F Test for Personal Ethical Philosophy, Internal Locus of Control, and Academic Culture on Professional Competence of Accountant Educators ANOVA $^{\text {b }}$

\begin{tabular}{|c|c|c|c|c|c|}
\hline del & Im of Squares & $\mathrm{Df}$ & Mean Square & $\mathrm{F}$ & Sig. \\
\hline gression & 643,861 & 3 & 214,620 & 16,760 & $.000^{\mathrm{a}}$ \\
\hline Residual & $.729,909$ & 57 & -12,805 & & \\
\hline Total & .1373 .770 & 60 & & & \\
\hline
\end{tabular}

a. Predictors : (Constant); Personal Ethical Philosophy (X1); Internal Locus of Control (X2); Academic Culture (X3)

b. Dependent Variable : Professional Competence of Accountant Educators (Y)

Source: Analyzed data, 2015

Table 4.3 showed that the value of F-calculated was 16.760 , more than F-table; 2.77 . The significance value was 0.000 , or less than the significance level $(\alpha)$ of 0.05 . Therefore, it can be concluded that Personal Ethical Philosophy, Internal Locus of Control, and Academic Culture, altogether, significantly affected Professional Competence of Accountant Educators in the Accounting Department. Thus, the hypothesis testing of Ha was accepted.

This result indicated that Personal Ethical Philosophy, Internal Locus of Control, and Academic Culture had a significant effect in enhancing Professional Competence of Accountant Educators. For that reason, efforts must be done to enhance the quality of leaders who can provide good examples to their personnel as well as cooperate with them, and augment self-motivation in enhancing Academic Culture so that the goals 
JARES, Vol. 4 No. 1 March, 2019; p-ISSN: 2502-826X; e-ISSN: 2503-1163

Copyrights@ Balitar Islamic University, Blitar, Indonesia;

https://ejournal.unisbablitar.ac.id/index.php/jares

Citation: Alam, S., \& Alam, R. (2019). THE EFFECT OF PERSONAL ETHICAL PHILOSOPHY, INTERNAL LOCUS OF CONTROL AND ACADEMIC CULTURE ON PROFESSIONAL COMPETENCE OF ACCOUNTANT EDUCATORS IN PRIVATE UNIVERSITIES IN MAKASSAR. JARES (Journal of Academic Research and Sciences), 4(1), 13-27. https://doi.org/10.30957/jares.v4i1.692

and targets of the organization can be achieved.

\section{Coefficient of Determination}

The analysis of the coefficient of determination for Personal Ethical Philosophy, Internal Locus of Control, and Academic Culture on Professional Competence of Accountant Educators was performed using the SPSS program as follows:

Table 4.4

The Result of the Coefficient of Determination Model Summary

\begin{tabular}{|c|c|c|c|c|c|}
\hline del & $\mathrm{R}$ & R Square & $\begin{array}{l}\text { Adjusted } \\
\text { R Square }\end{array}$ & $\begin{array}{l}\text { Std. Error of } \\
\text { the Estimate }\end{array}$ & $\begin{array}{l}\text { Durbin } \\
\text { Watson }\end{array}$ \\
\hline & $.685^{\mathrm{a}}$ & .469 & .441 & 3,578 & 1,649 \\
\hline
\end{tabular}

a. Predictors : (Constant) Personal Ethical Philosophy (X1); Internal Locus of Control (X2); Academic Culture (X3)

b. Dependent Variable: Professional Competence of Accountant Educators ( $\mathrm{Y}$ )

Source: Analyzed data, 2015

Table 4.4 showed that the value of the coefficient of determination was 0.441 , indicating that the effect of personal Ethical Philosophy, Internal Locus of Control, and Academic Culture on Professional Competence of Accountant Educators was $44.1 \%$. This suggested that $55.9 \%$ of Professional Competence was affected by other variables such as compensation, competence, work spirit, etc. It thus can be said that Accountant Educators as the change agents in Accounting Department will experience the improvement of performance if Personal Ethical Philosophy, Internal Locus of Control, and Academic Culture can reinforce the duties or programs performed by Accountant Educators

\section{DISCUSSION}

\section{Personal Ethical Philosophy with Professional Competence of Accountant Educators}

Personal Ethical Philosophy significantly affected Professional Competence of Accountant Educators by 0.210 or $21 \%$, in which the tcalculated of 2.085 was more than the t-table of 2.002 with the significance value of 0.042 , or less than the significance level $(\alpha)$ of 0.05 . This means that the values of the ethical system as the creator of self-concept for accountant educators provide a positive stimulus, building morality awareness in mastering their jobs. Hence, accountant educators have a high responsibility to commit to the competence in the field of accounting 
JARES, Vol. 4 No. 1 March, 2019; p-ISSN: 2502-826X; e-ISSN: 2503-1163

Copyrights@ Balitar Islamic University, Blitar, Indonesia;

https://ejournal.unisbablitar.ac.id/index.php/jares

Citation: Alam, S., \& Alam, R. (2019). THE EFFECT OF PERSONAL ETHICAL PHILOSOPHY, INTERNAL LOCUS OF CONTROL AND ACADEMIC CULTURE ON PROFESSIONAL COMPETENCE OF ACCOUNTANT EDUCATORS IN PRIVATE UNIVERSITIES IN MAKASSAR. JARES (Journal of Academic Research and Sciences), 4(1), 13-27. https://doi.org/10.30957/jares.v4i1.692

\section{Internal Locus of Control with Professional Competence of Accountant Educators}

Internal Locus of Control significantly affected Professional Competence of Accountant Educators by 0.210 or $21 \%$, in which the t-calculated of 2.185 was more than the t-table of 2.002 with the significance value of 0.035 , or less than the significance level $(\alpha)$ of 0.05 . This suggests that beliefs to the ability of self-control and situational-control will affect their commitment in doing their duties. Accountant educators think that their own abilities can change the situation to be better.

\section{Academic Culture with Professional Competence of Accountant Educators}

Academic Culture significantly affected Professional Competence of Accountant Educators by 0.274 or $27.4 \%$, in which the t-calculated of 2.146 was more than the t-table of 2.002 with the significance value of 0.036 , or less than the significance level $(\alpha)$ of 0.05 . It signals that a conducive academic culture will support accountant educators in doing their jobs and responsibilities well.

Personal Ethical Philosophy, Internal Locus of Control, and Academic Culture altogether significantly affected Professional Competence of Accountant Educators by 0.441 (41\%). Meanwhile, 55.9\% of the effects came from other variables not studied in this research. The value of F-calculated was 16.760 , and it was more than F-table of 2.77 with the significance value of 0.000 , or less than the significance level $(\alpha)$ of 0.5 .

\section{CONCLUSION AND SUGGESTION}

\section{A. Conclusion}

Personal Ethical Philosophy, Internal Locus of Control, and Academic Culture had significant effects on Professional Competence of Accountant Educators.

1. Personal Ethical Philosophy explaining the value system and building self-concept will contribute to the ability of Accountant Educators in doing their duties and responsibilities well.

2. Internal Locus of Control expounding internal control of individual will determine the ability of Accountant Educators in doing their duties and responsibilities well since there is always guidance to work according to the existing norms.

3. Academic Culture will facilitate Accountant Educators in exploring their ability in doing their duties and responsibilities as a professional 
Citation: Alam, S., \& Alam, R. (2019). THE EFFECT OF PERSONAL ETHICAL PHILOSOPHY, INTERNAL LOCUS OF CONTROL AND ACADEMIC CULTURE ON PROFESSIONAL COMPETENCE OF ACCOUNTANT EDUCATORS IN PRIVATE UNIVERSITIES IN MAKASSAR. JARES (Journal of Academic Research and Sciences), 4(1), 13-27. https://doi.org/10.30957/jares.v4i1.692

educator.

\section{B. Suggestions}

This study proposes the following suggestions:

1. Educational institutions responsible for shaping humans to be smart and professional should build a value system that will provide a unique character for the graduates.

2. Individual control needs to be conceptualized and build to each academician together with the building of value system in order that both concepts can holistically interact in shaping the character of the graduates.

3. Creating discussion media about the actual topics to provide enrichment and supplement knowledge to academicians as the form of self-actualization for the accountant educators, impacting the character of the graduates.

\section{REFERENCES}

Bertens, K. (2000). Pengantar Etika Bisnis. Kanisius Publisher Yogyakarta.

Cavanagh, G. F., D. J. Moberg, M. Velasquez. (1981). The ethics of organizational politics. The Academy of Management Review (pre1986). July. pp. 363.

Desriani, Rahmi. (1993). Persepsi Akuntan Publik terhadap Kode Etik Akuntan Indonesia. Master's Thesis Graduate Program of Gajah Mada University Yogyakarta (unpublished).

Daryatmi. 2005. Pengaruh Motivasi, Pengawasan Dan Budaya Kerja Terhadap Produktivitas Kerja Karyawan Perusahaan Daerah Bank Perkreditan Rakyat Badan Kredit Desa Kabupaten Karanganyar. Daryatmi's Article. Karanganyar. Vol.9, No 2, pp. 72-89. Jurnal Hasil Penelitian. Ums.ac.id.

Forsyth, D.R. (1980), A taxonomy of ethical ideologies, Journal of Personality and Social Psychology, Vol. 39, pp. 175-84.

Ghozali, Imam. 2005. Aplikasi Analisis Multivariate dengan Program SPSS. Semarang: BP Universitas Diponegoro. Semarang.

Guritno, Bambang, and Waridin. 2005. Pengaruh Persepsi Pegawai Mengenai Perilaku Kepemimpinan, Kepuasan Kerja Dan Motivasi 
Citation: Alam, S., \& Alam, R. (2019). THE EFFECT OF PERSONAL ETHICAL PHILOSOPHY, INTERNAL LOCUS OF CONTROL AND ACADEMIC CULTURE ON PROFESSIONAL COMPETENCE OF ACCOUNTANT EDUCATORS IN PRIVATE UNIVERSITIES IN MAKASSAR. JARES (Journal of Academic Research and Sciences), 4(1), 13-27. https://doi.org/10.30957/jares.v4i1.692

Terhadap Kinerja. JRBI. Vol 1. No 1. Pp: 63-74.

Gunawan, K. 2009. Pengaruh Budaya Organisasi, Kepuasan Kerja dan Motivasi Kerja terhadap Gaya Kepemimpinan dan Kinerja Organisasi (Studi pada Lembaga Perkreditan Desa (LPD) di Bali). Dissertation of Graduate Program of Brawijaya University, Malang.

Hyatt, T.A. dan Prawitt, D.F. 2001. Does congruence between audit structure and auditors locus-of-control affect job performance? The Accounting Review, Vol. 76 No. 2, pp. 263-74.

Kohlberg, L. 1971. Stage and Sequence: The Cognitive Developmental Approach to Socialization. In D. A. Goslin (Ed.), Handbook of Socialization Theory and Research. pp. 347-480. Chicago: Rand McNally.

Khomsiyah and Nur Indriantoro. 1998. Pengaruh Orientasi Etika terhadap Komitmen, dan Sensitivitas Etika Auditor Pemerintah di DKI Jakarta. Jurnal Riset Akuntansi Indonesia Vol 1 (1) Jan: 13-28.

Kotter, J.P., and James, L.H. 1997. Corporate Culture and Performance. New York: The Free Press A Division Simon \& Schuster Inc.

Ridwan. 2008. Metode dan Teknik Menyusun Tesis. Bandung: Alfabeta.

Robbins, Stephen P (2006), Organizational Behavior. 10th. Prentice-Hall. New Jersey.

Sekaran, Uma. 2006. Research Methods For Business: Metodologi Penelitian Untuk bisnis. Salemba Empat. Jakarta.

Sugiyono, 2009. Metode Penelitian Kuantitatif, Kualitatif dan R\&D. Bandung: Alfabeta

Sihwahjoeni and M. Gudono. 2000. Persepsi Akuntan terhadap Kode Etik Akuntan. Jurnal Riset Akuntansi Indonesia. Vol.3 (2) Juli: 168-184.

Sarita, J dan D. Agustia. 2009. Pengaruh Gaya Kepemimpinan Situasional, Motivasi Kerja, Locus of Control Terhadap Kepuasan Kerja dan Prestasi Kerja Auditor. Jurnal Akuntansi Universitas Airlangga.

Tika, P. 2006. Budaya Organisasi Dan Peningkatan Kinerja Perusahaan. PT Bumi Aksara. Jakarta. 
Citation: Alam, S., \& Alam, R. (2019). THE EFFECT OF PERSONAL ETHICAL PHILOSOPHY, INTERNAL LOCUS OF CONTROL AND ACADEMIC CULTURE ON PROFESSIONAL COMPETENCE OF ACCOUNTANT EDUCATORS IN PRIVATE UNIVERSITIES IN MAKASSAR. JARES (Journal of Academic Research and Sciences), 4(1), 13-27. https://doi.org/10.30957/jares.v4i1.692

Nugrahaningsih. 2005. "Analisis Perbedaan Perilaku Etis Auditor Di KAP dalam Etika Profesi (Studi Terhadap Peran Faktor-Faktor Individual: Locus of Control, Lama Pengalaman Kerja, Gender, dan Equity Sensitivity). SNA VIII Solo, 15-16.September.

Nur Indriantoro and Bambang Supomo. 1999. Metodologi Penelitian Bisnis. First Edition. BPFE. Yogyakarta.

Patten, M. D. 2005. An Analysis of The Impact of Locus of Control on Auditor internal Job Performance and Satisfaction, Managerial Auditing Journal, Vol. 20 No. 9, pp. 1016-1029.

Unti Ludigdo and Mas'ud Machfoedz, 1999. Persepsi Akuntan dan Mahasiswa terhadap Etika Bisnis. Jurnal Riset Akuntansi Indonesia. IAI. Vol.2. no.1. January. Pp 1-19.

Widjaja, A.W. 2003, Etika Administrasi Negara. Bumi Aksara, Jakarta.

Yanhari. 2007. Analisis Profesionalisme dan Etika Profesi Auditor terhadap Kinerja Auditor (Studi Kasus pada Badan Pemeriksa Keungan RI di Jakarta). Thesis Faculty of Economics Mercubuana University Jakarta.

Ziegenfuss, D. E., and Martinson, O. B. 2000. Looking at what influences ethical perception and judgment, Management Accounting Quarterly, Fall, pp. 41-47.

Zoraifi, R. 2005. Pengaruh Locus of Control, Tingkat Pendidikan, Pengalaman Kerja, dan Pertimbangan Etis Terhadap Perilaku Auditor dalam Situasi Konflik Audit”. Jurnal Akuntansi dan Bisnis, Vol.5 No.1, pp. 12-26. 